\title{
Research
}

\section{Economic Behavior in the Face of Resource Variability and Uncertainty}

\author{
$\underline{\text { Ryan R J McAllister }}^{1}, \underline{\text { John G. Tisdell }}^{2}, \underline{\text { Andrew F. Reeson }}^{1}{ }^{\text {, and Iain J. Gordon }}{ }^{1,3}$
}

\begin{abstract}
Policy design is largely informed by the traditional economic viewpoint that humans behave rationally in the pursuit of their own economic welfare, with little consideration of other regarding behavior or reciprocal altruism. New paradigms of economic behavior theory are emerging that build an empirical basis for understanding how humans respond to specific contexts. Our interest is in the role of human relationships in managing natural resources (forage and livestock) in semiarid systems, where spatial and temporal variability and uncertainty in resource availability are fundamental system drivers. In this paper we present the results of an economic experiment designed to explore how reciprocity interacts with variability and uncertainty. This behavior underpins the Australian tradable grazing rights, or agistment, market, which facilitates livestock mobility as a human response to a situation where rainfall is so variable in time and space that it is difficult to maintain an economically viable livestock herd on a single management unit. Contrary to expectations, we found that variability and uncertainty significantly increased transfers and gains from trade within our experiment. When participants faced variability and uncertainty, trust and reciprocity took time to build. When variability and uncertainty were part of the experiment trust was evident from the onset. Given resource variability and uncertainty are key drivers in semiarid systems, new paradigms for understanding how variability shapes behavior have special importance.
\end{abstract}

Key Words: agistment; experimental economics; grazing; investment game; livestock mobility; nomadism; reciprocity; trust game

\section{INTRODUCTION}

Humans thrive in our complex social-ecological systems by relying on highly context specific social institutions, i.e., norms, that condense the learnings from our evolutionary history. Although traditional economic models of human behavior miss this richness (see Gowdy 2008), new paradigms are being developed that more accurately explain behavior in the context of social and ecological settings. Economic experiments have been a key tool in moves toward these new paradigms. In this paper we employ an economic experiment to explore the role of resource variability in shaping behavior.

Experimental economics builds an empirical basis for understanding how humans respond to incentives in specific contexts. The experiments are games, with various degrees of contextualization and abstraction, played by real people for real payments. Conceptual models of institutional design (e.g., Anderies et al. 2004) have emerged alongside experimental evidence confirming sanctions, communication, and group boundaries, i.e., property rights (e.g., Ostrom et al. 1992, Schmitt et al. 2000, Tisdell et al. 2004, Henrich et al. 2006, Ahn et al. 2009, Janssen et al. 2010), are important elements in promoting reciprocity when managing contested resources. Our interest is in how humans manage natural resources in semiarid systems. In semiarid systems, in addition to the challenges of natural resource contestation, extreme resource variability shapes all aspects of life, from plants and animal life strategies (e.g., Chesson et al. 2004, Morton et al. 2011) to the ways in which humans manage environmental resources. However, experimental evidence explicitly relating to variability's effect on human behavior is still limited.

Grazier management of forage resources for livestock production is of international concern, both because of the vast areas of semiarid, and arid, 
land used for domestic livestock production and because grazing is a critical activity for semiarid rural livelihoods (Reynolds et al. 2007). Grazier responses to spatio-temporal forage variation are well documented, particularly in some African nations (e.g., Perevolotsky 1987, Niamir-Fuller 1998, Boone et al. 2011), but also in western grazing cultures (e.g., McAllister et al. 2006, Huntsinger et al. 2010, Manzano and Casas 2010). Although formal institutional settings can vary greatly across and within African and western cases, there are some simple informal institutional elements that appear to be consistent requirements. Trust is critical in that it is required to give some degree of confidence that cooperative behaviors will be reciprocated. At the heart of trust and reciprocity are social institutions that facilitate, often imperfectly, contextualized communication, sanctions, and rewards. More broadly, in addition to social behavior, institutional and ecosystem dynamics need to be integrated to understand vulnerability in semiarid regions (e.g., Dougill et al. 2010, Dong et al. 2011).

The Australian tradable grazing rights, or agistment, market facilitates livestock mobility as a human response to a situation in which rainfall is so variable in time and space that it is difficult to maintain an economically viable livestock herd on a single management unit (Reeson et al. 2008). Agistment interactions match pastoralists who have a shortage of forage, i.e., agistors, with pastoralists who have an excess, i.e., agistees. Although each agistment interaction is essentially a one-off business transaction, long-term relationships within agistment networks can facilitate reciprocity and repeated agistment interactions over many years and decades.

The returns from agistment are highly uncertain, particularly for the agistor, the grazier who temporarily moves livestock onto another grazier's property, frequently more than $200 \mathrm{~km}$ away (Reeson et al. 2008). Although some agistment interactions are between trusted friends, many are between strangers. Further, even graziers who know each other will still express mutual uncertainty about how they expect each other to behave in agistment interactions. Agistment markets also tend to be based on informal agreements, or social contacts. The agistor can never be sure in what condition their livestock will be returned, or the number of livestock losses. Further, because of highly localized environmental variability as well as variable management by the agistee, i.e., landholder, attribution of any condition and losses of the agistor's livestock is rarely certain. Tradable grazing rights are an important tool for allowing graziers to deal with variability across space, and this is particularly important in countries where once mobile livestock herders become sedentary.

Theories from behavioral psychology indicate that variability and uncertainty should reduce cooperative behavior within our experimental design. Prospect theory generally assumes a degree of risk aversion (see Hastie and Dawes 2001). Hence, for the agistor, this weights the risk of losses in the agistment market relatively more highly than any potential gains. Increased variability therefore creates both greater gains and losses, but risk adverse decision makers will place more importance on the potential for greater losses, effectively decreasing the perceived benefits from entering the agistment market in the first place.

Empirically, economic experiments have been used to explore the impact of incomplete, asymmetric, or uncertain information in various settings. In ultimatum games, one player transfers a proportion of a reward to a second player, who then decides if both players are allowed to keep their allocations. Where the second player does not know the total size of the reward, the amount offered decreases as uncertainty increases (Croson 1996, Rapoport et al. 1996). In trust or investment games, one player transfers an amount to a second player. This transfer is multiplied to signify gains from trade and the second player chooses how much to return to the first. Dufwenberg et al. (2001) added variability to the multiplier applied to transfers made to the second player, and uncertainty in that only the first player knew the multiplier used. They found an insignificant decrease in transfers. In a similar game that included repeated play, Coricelli et al. (2006) found no impact of uncertainty. However, Kanagaretnam et al. (2010) found that concealing information about the size of endowments, but while revealing the mean endowment level, did reduce transfers.

In our study we analyze an economic experiment designed to inform how cooperative behavior interacts with variability specifically with regards to the uncertainty faced by agistors. This issue underpins the success of the agistment market (Reeson et al. 2008). We used a modified trust game. In a standard trust game (e.g., Berg et al. 1995) 
transfers from first movers are adjusted prior to reaching the second mover. This does not reflect the nature of agistment interactions. In agistment interactions, transfers of livestock from the first mover, i.e., the agistor, reach the second mover, i.e., the agistee, exactly as sent. The gains from trade are generated by the actions of the second mover. To capture this important aspect of the interaction we use a modified version of the standard trust game, following Reeson et al. (2011), in which the multiplier is applied to the second mover's transfer rather than the first mover's. This extends previous research by using an experimental scenario designed for specific relevance to the tradable grazing rights market, which is characterized by high degrees of environmental and social uncertainty. Based on past studies and theory, we expect our experiment to show that uncertainty is likely to compound the challenges particular to the agistment market and reduce transfer levels accordingly.

\section{METHODS}

Our economic experiment was designed to explore a particular aspect of uncertainty and variability that underpins the agistment market, following the approach described by Reeson et al. (2011). Participants were divided into two equally sized sets of players, representing livestock owners, i.e., agistors, and landholders, i.e., agistees. Participants remained in their assigned set throughout the whole session. The decisions of the first mover in the experiment represent those made by a livestock owner deciding how many livestock to entrust to a landholder. The decisions of the second mover represent those made by the landholder in deciding how much effort to invest in looking after those livestock. It has parallels with the standard trust/ investment economic experiment (Berg et al. 1995), though in our case the gains from trade come from the second mover responding, because the effort invested by the landholder is key to the outcome of agistment agreements.

The participants in the experiment had the opportunity to enter into partnerships with others, but with no means of entering into or enforcing binding contracts. This reflects the reality of agistment agreements, being mostly informal given the difficulty of fully or formally specifying conditions of such an arrangement (Reeson et al.
2008). In the experimental scenario, participants could choose a partner, or they could choose not to enter the market at all. Participants were anonymous outside of the experiment, identified within the experiment only by a number. For those who formed partnerships, the first mover decided how much money to entrust to their partner, then the second mover decided how much to send back. If the second mover responded, then the amount they transfer was multiplied, representing the gains from trade. This differs from the standard trust game, in which the multiplier applies to the first mover's transfer, reflecting the fact that in agistment agreements it is the actions of the second mover that result in the gains. For the interaction to be profitable to both players, trust and reciprocity are required.

The key treatment, and the focus of this analysis, involved differing levels of environmental and social stochasticity, represented by variability in the multiplier applied to the transfers made by the second mover. This multiplier was either a constant 4 ('fixed') or a random sequence varying from 2 to 6 ('variable'). The same sequence was used for each variable session $(4.0 ; 5.1 ; 2.9 ; 5.8 ; 2.2 ; 4.9 ; 5.9 ; 3.1$; $4.0 ; 2.1)$. When fixed, both first and second movers knew the multiplier was 4 . When variable, both knew the multiplier varied from 2 to 6 , but only the second mover knew exactly what multiplier was applied in a given interaction. In the variable treatment, the multiplier value was never revealed to the first mover. This reflects the variability typical of semiarid grazing environments in Australia combined with local knowledge; the person managing the property understands local variability much better than an outsider and they have the benefit of directly observing local environmental conditions and management.

A second treatment involved the presence or absence of a 'rating' mechanism, whereby participants could publicly express their level of satisfaction with their partner, similar to the mechanism used on eBay. Participants assigned their partner a satisfaction rating when the transfers were complete; in the 'no rating' treatments, this step was simply omitted from the experiment. We included this rating mechanism in our design because there have been local debates on whether an eBay style agistment market would be effective. The reputation mechanism is not explicitly analyzed here, but was the focus of an early analysis based on a subset of observations (see Reeson et al. 2011). 
Table 1. Treatments used in the experiment.

\begin{tabular}{lcc}
\hline \hline Multiplier & Rating & No rating \\
\hline Fixed at 4 & $\begin{array}{c}\text { Fixed, rating treatment } \\
\text { (3 repetitions with 10 players per } \\
\text { repetition) }\end{array}$ & $\begin{array}{c}\text { Fixed, no rating treatment } \\
\text { (3 repetitions with 10 players per } \\
\text { repetition) }\end{array}$ \\
Varied between 2-6 & $\begin{array}{c}\text { Variable, rating treatment } \\
\text { (3 repetitions with 10 players per } \\
\text { repetition) }\end{array}$ & $\begin{array}{c}\text { Variable, no rating treatment } \\
\text { (3 repetitions with 10 players per } \\
\text { repetition) }\end{array}$ \\
\hline
\end{tabular}

In this study three independent sessions of each treatment combination were conducted (Table 1). Overall we carried out 12 experimental sessions, comparing the fixed and variable multiplier treatments in a two-by-two orthogonal design (Table 1).

The experiments were conducted with students at Griffith University in Brisbane, Australia, in a computer laboratory using specialized experimental software. Participants were randomly selected from a database of students who had registered to take part in experiments, across all faculties and year cohorts at the university. On arrival at the experiment they were asked to read a set of instructions on the computer before answering a series of questions designed to ensure that they understood the instructions. Researchers were available to provide assistance where required. Once all the questions were answered correctly participants could access the experimental interface. Participants were not permitted to interact during the experiments apart from through the software. As is standard practice in experimental economics, participants were paid, confidentially, and in cash, at the end of the experiment. Copies of the instructions are available in an Appendix.

For each experimental session, the number of rounds was not known to participants in advance; the experiment ended after 10 rounds, and without warning to avoid end effects. For each round, the experimental procedure consisted of a series of stages, explained in more detail below:

- Stage 1: participants select partners

- Stage 2: first movers transfer money to partner
- Stage 3: second movers transfer money, which is multiplied, to partner

- $\quad$ Stage 4 (rating treatments only): partners simultaneously rate each other

At the beginning of each round, players could enter into partnerships, formed between a first mover and a second mover. They could do this by entering the identification (ID) number of the player with whom they wished to form a partnership. Participants remained anonymous from each other, apart from their experimental ID number (1-10).

Those players available to form a partnership were indicated on participants' screens. A partnership was formed when two participants entered each other's numbers, thereby rendering these players unavailable to other participants. Participants were allowed up to three minutes to choose a partner, entering as many numbers as they wished until they had formed a partnership. Each player could partner with only one other player in each round, or they could choose not to enter into a partnership at all. Because each experiment session had 10 participants, divided into two equal groups, should one player choose not to enter into a partnership, then one other player would naturally be unable to form a partnership. Players' intentions were not indicated at this stage because no further information was provided to participants.

With an endowment of 100 monetary units for each player per round $(100=$ one Australian dollar in experimental earnings), the first mover in a partnership was required to transfer at least 10 to their partner (maximum was 100). One Australian dollar was approximately worth US\$0.80, Euro 
0.52, and Pound 0.50 at the time the experiments were run. Upon seeing the amount they received, the second mover then made a return transfer to their partner, being a minimum of 1 and a maximum of their total holding, i.e., their 100 unit endowment plus the amount received from the first mover. The amount of the return transfer was then multiplied, by 4 in the fixed treatment or by a value from 2-6 in the variable treatment, representing gains from a successful interaction. Participants without partners retained their initial endowment of 100 . Participants' screens were updated during each round to show with whom they were partnered, how much they had sent to and received from their partner, and their total payoff for that round.

Partnerships dissolved at the end of each round. At the start of the next round participants could again seek a partner. They were not required to remain with the same partner as in the previous round. Participants' player numbers remained constant throughout the experiment, enabling participants to be identified within the experiment. In the no rating treatments, once the second mover had made their return transfer, the interaction was complete. However, in the rating treatments, partners needed to take the additional step of providing each other with a rating. Ratings were given on a scale of one to three: one indicating unhappy; two neutral; three happy. Ratings were made simultaneously, so participants had to enter a rating before they saw the rating they received from their partner. Ratings received by each of the 10 participants, along with who their partner had been, were publicly displayed on participants' screens; these did not appear until all participants had entered a rating. However, the amounts of money transferred between partners were not publicly displayed.

\section{RESULTS}

Our results are based on an analysis of participant transfers between first and second movers. We examined how including variation in the return multiplier, as a proxy for natural variation in resource abundance and heterogeneity in human behavior, impacted on transfers in an experiment designed to explore behavior underpinning the functioning of the agistment market. We refer throughout to both variability and uncertainty. By variation we mean variation in the factor by which second mover transfers were multiplied before reaching the first mover partner. Uncertainty refers to the fact that when the multiplier was allowed to vary between 2 and 6, only the second movers knew its value in any given interaction.

Table 2 presents the average transfers by first and second movers in the fixed and variable treatments in each of the 10 rounds of the experiment. In the fixed treatment, first movers transferred an average of 61.5, with second movers returning an average of 24.3, which was multiplied by four. In the variable treatment, overall transfers were higher, with first movers transferring an average of 80.3 and second movers returning 45.5 , which was multiplied by between 2 and 6 (see Fig. 1).

When examining only the first round, both the first and second mover transfers were higher in the variable treatment (Fig. 2). The trends in transfers over all rounds indicate that variable and fixed treatments exhibit different patterns (Table 2). In the fixed treatment, transfers started out relatively low, with first movers sending 48.2 in the first round, and second movers returning an average of 17.6. These transfers tended to increase over the next few rounds of the experiment, before plateauing in the sixth round (Table 2). In the variable treatment, average transfers were high right from the start, with 72.3 and 46.3 transferred by first and second movers, respectively, in the initial round.

In the variable treatment, players were more likely to retain the same partner between rounds (see Fig. 3 ). On average, players retained their partner from the previous round on $66 \%$ of occasions under the variable treatment, compared with $40 \%$ in the fixed multiplier treatment. In the fixed treatment, the stability of partnerships increased distinctly throughout the rounds. In the second round, only $17 \%$ of partnerships were retained from the first round, compared with $70 \%$ in the variable treatment. By the 10th and final round, $67 \%$ of fixed treatment partnerships were retained from the 9th round.

A series of random effects panel data models were estimated using STATA 11.1. The panel data models of transfers are shown in Table 3 . Explanatory variables included a dummy variable for the variable treatment, a dummy variable for the rating treatment, a variable for the number of consecutive rounds over which a partnership had lasted (1 for a new partnership, 2 if this was the second consecutive round in which two players had 
Table 2. Mean behavior over 10 rounds.

\begin{tabular}{|c|c|c|c|c|c|c|c|c|}
\hline \multirow[b]{2}{*}{ Round } & \multicolumn{4}{|c|}{ Fixed treatment } & \multicolumn{4}{|c|}{ Variable treatment } \\
\hline & $\begin{array}{l}\text { 1st Mover } \\
\text { transfer }\end{array}$ & $\begin{array}{c}\text { 2nd Mover } \\
\text { transfer }^{\dagger}\end{array}$ & Multiplier & $\begin{array}{l}\text { Retained } \\
\text { partner }\end{array}$ & $\begin{array}{l}\text { 1st Mover } \\
\text { transfer }\end{array}$ & $\begin{array}{c}\text { 2nd Mover } \\
\text { transfer }^{\dagger}\end{array}$ & Multiplier & $\begin{array}{l}\text { Retained } \\
\text { partner }\end{array}$ \\
\hline 1 & 48.2 & 17.6 & 4.0 & n.a & 72.3 & 46.3 & 4.0 & n.a. \\
\hline 2 & 48.8 & 19.3 & 4.0 & $17 \%$ & 79.1 & 60.6 & 5.1 & $70 \%$ \\
\hline 3 & 54.7 & 23.3 & 4.0 & $20 \%$ & 79.0 & 45.3 & 2.9 & $63 \%$ \\
\hline 4 & 58.5 & 23.6 & 4.0 & $27 \%$ & 82.1 & 44.2 & 5.8 & $47 \%$ \\
\hline 5 & 65.5 & 26.4 & 4.0 & $50 \%$ & 81.0 & 41.4 & 2.2 & $73 \%$ \\
\hline 6 & 59.4 & 25.4 & 4.0 & $50 \%$ & 82.3 & 44.6 & 4.9 & $67 \%$ \\
\hline 7 & 71.0 & 25.4 & 4.0 & $37 \%$ & 82.9 & 45.6 & 5.9 & $73 \%$ \\
\hline 8 & 65.6 & 25.6 & 4.0 & $37 \%$ & 82.1 & 41.0 & 3.1 & $73 \%$ \\
\hline 9 & 75.0 & 29.9 & 4.0 & $57 \%$ & 81.4 & 39.5 & 4.0 & $67 \%$ \\
\hline 10 & 72.6 & 27.9 & 4.0 & $67 \%$ & 80.5 & 46.5 & 2.1 & $60 \%$ \\
\hline Mean & 61.5 & 24.3 & 4.0 & $40 \%$ & 80.3 & 45.5 & 4.0 & $66 \%$ \\
\hline
\end{tabular}

$\dagger$ Mean Second Mover transfers are before application of the multiplier.

$\ddagger$ Retained partner refers to the percentage of partners that retained the same partnership from the previous round.

been partnered with one another, etc.), a dummy variable for whether an interaction involved a new partner (partner change), and the multiplier level.

The rating treatment had no significant impact on transfers in any of the models. Considering all treatments combined (eqns. 1a, 2a in Table 3), transfers were significantly higher for both first and second movers in the variable treatment compared with the fixed treatment. Although partnership duration was not significant, transfers were significantly lower for newly formed partnerships (eqns. 1a, 2a in Table 3; partner change =1).

Considering only the fixed treatment, partnership duration showed a significant positive association with transfers by first movers (equation 1b) but not second movers (eqn. 2 b in Table 3 ); transfers to new partners were significantly lower for second movers but not for first movers. In the variable treatment, transfers were again significantly lower for new partnerships, while partnership duration was not significant (eqns. 1c, 2c in Table 3). Second mover transfers were not significantly associated with the multiplier level (eqn. $2 \mathrm{c}$ in Table 3 ).

\section{DISCUSSION}

In our experiment we measured the behavior of 120 participants in a controlled setting. Our observations allow us to examine one specific case of how uncertainty and variability influence behavior in an experimental setting. Our design also limited our analysis of behavior to questions of how much, rather than when or where action occurs (see Janssen 2010). Although participants bring into each experimental session their own set of social norms 
Fig. 1. Transfers within 'fixed' and 'variable' multiplier treatments, from (a) first to second mover, and (b) second to first mover as a percentage of transfers received. Transfers are per participant, averaged across all rounds. Data shown as box-whisker plots with median, 25 , and 75 percentile ranges and outliers, and with the horizontal bars showing minimum and maximum excluding outliers.

(a) Transfers from First to Second Mover
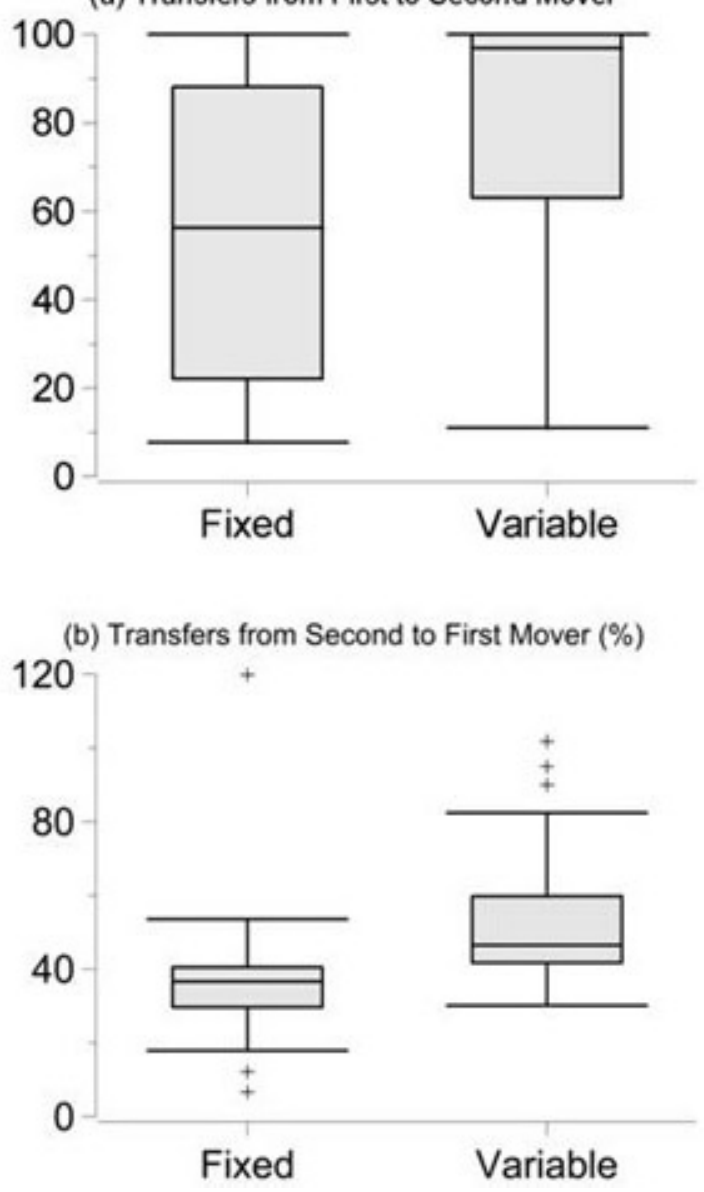

and values, our results showed significant and interesting differences between contextual treatments with and without variability in the multiplier applied to transfers, and uncertainty and asymmetrical information in that only the second mover knew the value of the variable multiplier in any individual interaction.

Our experiment built into its design the notion that trust, although risky, has the potential to increase the material payoffs for individual participants. The risk is that if trust is not reciprocated, payoffs for trusting individuals will decrease. Our results showed significant transfers above the do-nothing level. This is not a particularly novel finding given the wealth of evidence showing humans are not strictly self-regarding (e.g., Gintis 2000, Fehr and Fischbacher 2002). What is more exciting is the evidence that variability and uncertainty can induce greater trust and reciprocity.

Repeated interactions between partners boosts trust, as shown in first mover transfers. Our results also indicated players facing additional variation in their returns, in the variable treatment, had fewer partners when compared with having fixed returns, i.e., the fixed treatment. This implied the variable treatment was associated with more stable partnerships. Interestingly, although the variable treatment was associated with comparatively stable relationships 
Fig. 2. First round transfers within 'fixed' and 'variable' multiplier treatments, from (a) first to second mover, and (b) second to first mover as a percentage of transfers received. Transfers are per participant, averaged across all rounds. Data shown as box-whisker plots with median, 25, and 75 percentile ranges and outliers, and with the horizontal bars showing minimum and maximum excluding outliers.

(a) First round transfers by First Mover
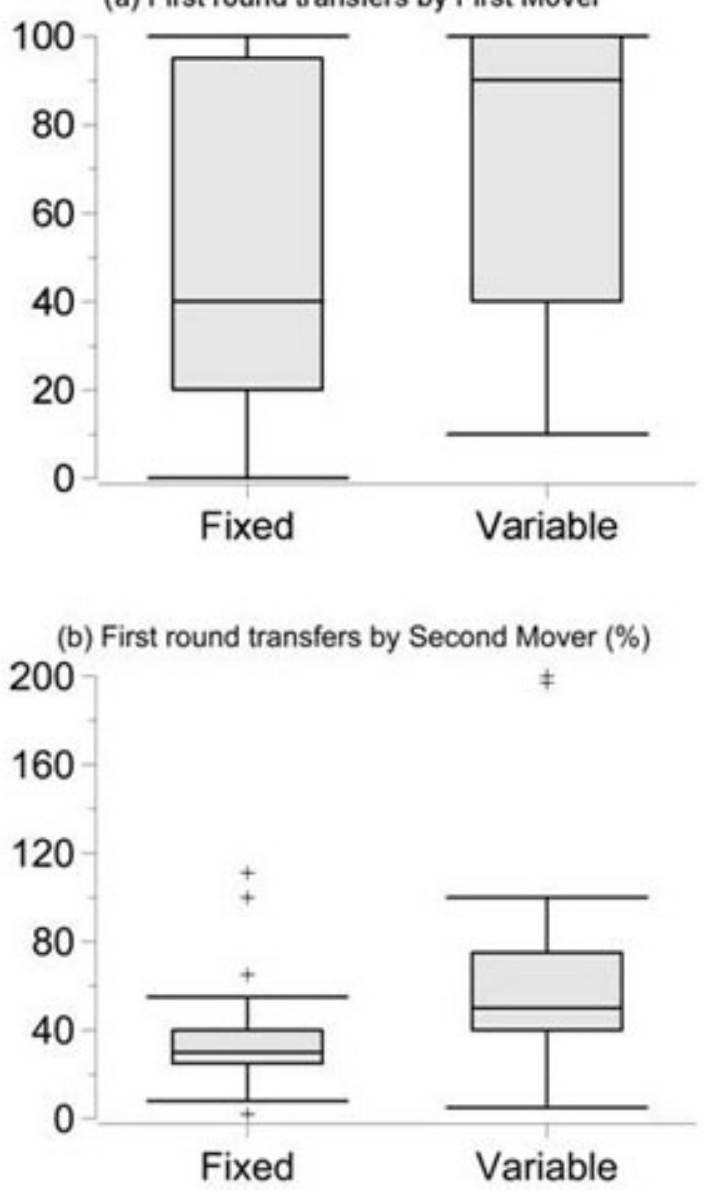

over all experimental rounds, in the fixed treatment the stability of relationships built over the rounds, and this was associated with correspondingly increasing transfers from both first and second movers.

The link we found between partnership stability and trust and reciprocity is consistent with previous studies (e.g., Kanagaretnam et al. 2010). The link between variability and uncertainty, and higher trust and reciprocity contradicts other published studies. Abbink and Herrimann (2011) found that uncertainty led to antisocial behavior. Previous trust experiments similarly show variability and uncertainty lead to lower levels of trust (Croson
1996, Rapoport et al. 1996, Kanagaretnam et al. 2010). We cannot be certain about the processes that underpin our contradictory findings. However, we propose various alternative explanations.

In the variable treatment, the first movers only knew what the multiplier averaged (i.e., 4). Perhaps because they did not know the specific value in a given interaction, the first movers were more forgiving on receiving less in an interaction. What a first mover received was the transferred amount multiplied by the variable multiplier. Hence, on receiving a small payoff a first mover may still have persisted in a partnership in subsequent rounds believing the small amount received was the result 
Fig. 3. Distribution (histogram) of the number of partners who interacted over the course of 10 experimental rounds. Black shading represents all 60 players in the 'fixed' treatment. Gray shading represents all 60 players in the 'variable' treatment.

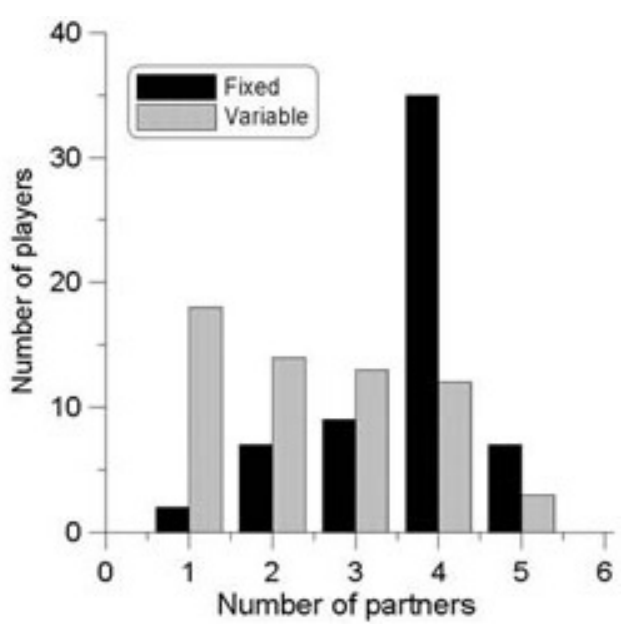

of the multiplier. Alternatively, knowing the first mover was unaware of the multiplier value in the variable treatment, the second mover may have sent more as a means of signaling value in their relationship. However, the first movers did much better overall under variability, while the second movers did not. Further, these explanations fail to explain the first mover, first round effects.

Although risk aversive behavior suggests the variable treatment should have smaller transfers, the reverse would be true for risk seekers. Small payoffs may encourage participants to seek more risk (Lefebvre et al. 2010). The payoffs in our experiment were very small relative to those associated with the agistment market. Hence, the interaction between incentive sizes and risk may be an influencing factor in our results and cautions against their application in the absence of further testing. Another plausible explanation for the higher amount sent by the first mover in the first round of the variable treatment experimental sessions might be that uncertainty leads to betrayal aversion. In essence there is no consistent explanation for these comparatively high first mover transfers in the variability treatment.

Although the underpinning processes need further exploration, if variability and uncertainty do bring out the reciprocal traits of human behavior, then relationships will be more stable, hence we may expect less social variability induced by changing social links. In contrast, our results also showed that the difference between first and second movers is more pronounced when we introduce variability and uncertainty. This may be a factor of our design, given first movers are always first movers. However, if payoff disparities are generated by variability, then this works against equity and social cohesion. As demonstrated in economic experiments, such disparities, including order of play, decrease cooperation (e.g., Ahn et al. 2007)

In terms of natural resource management, and in particular opportunistic movement of livestock in semiarid systems, if you do not take risky opportunities to move livestock to country where the productivity is higher, the output of the system is reduced. Our results, as discussed, suggest that dealing with variability may be embedded within our social norms; trust seemed to be more strongly rewarded in the more variable system. This provides new domains for research that have special importance for managing natural resources characterized by very high levels of variability. 
Table 3. Panel data analysis of transfers.

\begin{tabular}{|c|c|c|c|c|c|c|c|c|}
\hline Equation & Measure & Constant & $\begin{array}{l}\text { Variable } \\
\text { Treatment }\end{array}$ & $\frac{\text { Rating }}{\text { Treatment }}$ & $\begin{array}{c}\text { Partner } \\
\text { duration }\end{array}$ & $\begin{array}{l}\text { Partner } \\
\text { change | }\end{array}$ & Multiplier & Wald Statistic \\
\hline $\begin{array}{l}\text { 1a: Both } \\
\text { treatments }\end{array}$ & $\begin{array}{c}\text { First } \\
\text { Mover } \\
\text { Transfer }\end{array}$ & $\begin{array}{c}65.25 \\
(5.81)^{* *}\end{array}$ & $\begin{array}{c}17.23 \\
(6.42)^{* *}\end{array}$ & $\begin{array}{l}-4.26 \\
(6.40)\end{array}$ & $\begin{array}{c}0.63 \\
(0.52)\end{array}$ & $\begin{array}{c}-6.35 \\
(1.58)^{* *}\end{array}$ & & $41.10^{* *}$ \\
\hline $\begin{array}{l}\text { 1b: Fixed } \\
\text { only }\end{array}$ & $\begin{array}{c}\text { First } \\
\text { Mover } \\
\text { Transfer }\end{array}$ & $\begin{array}{c}58.26 \\
(7.93)^{* *}\end{array}$ & & $\begin{array}{c}-0.82 \\
(10.08)\end{array}$ & $\begin{array}{c}2.76 \\
(1.17)^{*}\end{array}$ & $\begin{array}{l}-4.92 \\
(2.70)\end{array}$ & & $23.79 * *$ \\
\hline $\begin{array}{c}\text { 1c: } \\
\text { Variable } \\
\text { only }\end{array}$ & $\begin{array}{l}\text { First } \\
\text { Mover } \\
\text { Transfer }\end{array}$ & $\begin{array}{l}87.21 \\
(5.36)^{* *}\end{array}$ & & $\begin{array}{l}-8.58 \\
(7.10)\end{array}$ & $\begin{array}{l}-0.18 \\
(0.44)\end{array}$ & $\begin{array}{c}-5.82 \\
(1.87)^{* *}\end{array}$ & & $12.36^{*}$ \\
\hline $\begin{array}{l}\text { 2a: Both } \\
\text { treatments }\end{array}$ & $\begin{array}{l}\text { Second } \\
\text { Mover } \\
\text { Transfer }\end{array}$ & $\begin{array}{c}34.04 \\
(4.60)^{* *}\end{array}$ & $\begin{array}{c}18.21 \\
(4.10)^{* *}\end{array}$ & $\begin{array}{l}-2.89 \\
(4.01)\end{array}$ & $\begin{array}{l}-0.48 \\
(0.74)\end{array}$ & $\begin{array}{c}-12.34 \\
(3.19)^{* *}\end{array}$ & & $45.62 * *$ \\
\hline $\begin{array}{l}\text { 2b:Fixed } \\
\text { only }\end{array}$ & $\begin{array}{l}\text { Second } \\
\text { Mover } \\
\text { Transfer }\end{array}$ & $\begin{array}{c}29.00 \\
(4.38)^{* *}\end{array}$ & & $\begin{array}{l}-1.69 \\
(4.81)\end{array}$ & $\begin{array}{c}0.58 \\
(0.79)\end{array}$ & $\begin{array}{c}-8.95 \\
(2.51)^{* *}\end{array}$ & & $26.97 * *$ \\
\hline $\begin{array}{c}\text { 2c: } \\
\text { Variable } \\
\text { only }\end{array}$ & $\begin{array}{l}\text { Second } \\
\text { Mover } \\
\text { Transfer }\end{array}$ & $\begin{array}{c}48.14 \\
(9.38)^{* *}\end{array}$ & & $\begin{array}{l}-4.12 \\
(6.21)\end{array}$ & $\begin{array}{l}-0.26 \\
(1.11)\end{array}$ & $\begin{array}{l}-14.67 \\
(5.88)^{*}\end{array}$ & $\begin{array}{c}1.21 \\
(1.45)\end{array}$ & 9.26 \\
\hline
\end{tabular}

$\dagger 0$ = fixed; 1 = variable

$\ddagger 0=$ no rating; 1 = rating

$\S$ number of consecutive interactions with same partner

$1=$ not the same partner as in previous round

* significant at $0.05 ; *$ significant at 0.01 ; Standard errors in brackets

\section{Context vs. culture?}

From a broader perspective, it is worth considering the implications of our results in explaining what makes semiarid systems unique. When participants partake in economic experiments their actions are a function of both individual existing social norms and the context of the experiment. In Australia there are both conceptual and observable differences between social networks in semiarid and more urbanized systems (McAllister et al. 2008, Stafford Smith 2008). However, economic experiments comparing reciprocity between semiarid rural and urban dwellers, although based on those in their late- teens, were unable to find any significant differences (McAllister and Reeson 2007). Our results show that variability induces greater transfers and may provide the clue to explaining the differences between semiarid and urban areas within a country. Regardless of the culture within which an individual is embedded, any context that has exogenous variability and uncertainty as key drivers may induce more trusting and reciprocal behavior. In other words, it is the context of regions that drive differences in observed behaviors rather than any differences in the underlying social norms. Prediger et al. (2011) recently tried unsuccessfully to disentangle ecological and social historical 
drivers of behavior. Although further testing is required, our findings anecdotally support the view that policies purporting to support those who choose to live outside of urbanized regions need to be more tailored to local contexts (e.g., Stafford Smith 2008).

\section{CONCLUSIONS}

New paradigms of economic behavior theory have explored how individuals respond according to existing social institutions, i.e., norms, and also to the specific contextual settings. Our results showed that variability and uncertainty are important elements of context. This has particular relevance in managing resources in semiarid settings, because here, variability and uncertainty tend to be extreme, and tend to permeate throughout most sectors of these social-ecological systems (Stafford Smith 2008). In semiarid grazing systems, both practical (e.g., Ash et al. 2002) and theoretical research (e.g., Anderies et al. 2002, Müller et al. 2007) point to the economic importance of long-term ecological sustainability. This needs to be balanced with shortterm production or livelihood goals. Livestock mobility is one example of how social institutions are critical in managing natural resources in these areas. Our results, rather than being definitive, speculate on the importance of variability and uncertainty in shaping behavior, and this opens up avenues for future research.

Responses to this article can be read online at: http://www.ecologyandsociety.org/voll6/iss3/art6/responses/

\section{Acknowledgments:}

Many thanks to Jana Crooks and Corinne Grainger for assistance in running the experiments, to Kirsten Maclean, James Laurenceson, John McIvor, and three anonymous reviewers for valuable comments, and to CSIRO's Climate Adaptation Flagship and IVCF program for funding. An earlier version of this paper was presented at the 2010 North American Regional Meeting of the International Association for the Study of the Commons.

\section{LITERATURE CITED}

Abbink, K., and B. Herrimann. 2011. The moral costs of nastiness. Economic Inquiry 49 (2):631-633. http://dx.doi.org/10.1111/j.1465-7295 $.2010 .00309 . \mathrm{x}$

Ahn, T. K., J. Esarey, and J. T. Scholz. 2009. Reputation and cooperation in voluntary exchanges: comparing local and central institutions. Journal of Politics 71(2):398-413. http://dx.doi.org/10.1017/S $\underline{0022381609090355}$

Ahn, T. K., M. Lee, L. Ruttan, and J. Walker. 2007. Asymmetric payoffs in simultaneous and sequential prisoner's dilemma games. Public Choice 132 (3-4):353-366. http://dx.doi.org/10.1007/s11127-00 7-9158-9

Anderies, J. M., M. A. Janssen, and E. Ostrom. 2004. A framework to analyze the robustness of socialecological systems from an institutional perspective. Ecology and Society 9(1): 18. [online] URL: http:// www.ecologyandsociety.org/vol9/iss1/art18/

Anderies, J. M., M. A. Janssen, and B. H. Walker. 2002. Grazing management, resilience, and the dynamics of a fire-driven rangeland system. Ecosystems 5(1):23-44. http://dx.doi.org/10.1007/s 10021-001-0053-9

Ash, A., J. Corfield, and T. Ksiksi. 2002. The Ecograze project: developing guidelines to better manage grazing country. CSIRO Sustainable Ecosystems, Townsville, Australia.

Berg, J., J. Dickhaut, and K. McCabe. 1995. Trust, reciprocity, and social history. Games and Economic Behavior 10(1):122-142. http://dx.doi.or $\mathrm{g} / 10.1006 /$ game.1995.1027

Boone, R. B., K. A. Galvin, S. B. BurnSilver, P. K. Thornton, D. S. Ojima, and J. R. Jawson. 2011. Using coupled simulation models to link pastoral decision making and ecosystem services. Ecology and Society 16(2): 6. [online] URL: http://www.eco logyandsociety.org/vol16/iss2/art6/

Chesson, P., R. L. E. Gebauer, S. Schwinning, N. Huntly, K. Wiegand, M. S. K. Ernest, A. Sher, A. Novoplansky, and J. F. Weltzin. 2004. Resource pulses, species interactions, and diversity maintenance in arid and semiarid environments. 
Oecologia 141(2):236-253. http://dx.doi.org/10.1007/ s00442-004-1551-1

Coricelli, G., L. González Morales, and A. Mahlstedt. 2006. The investment game with asymmetric information. Metroeconomica 57 (1):13-30.

Croson, R. T. A. 1996. Information in ultimatum games: an experimental study. Journal of Economic Behavior \& Organization 30(2):197-212. http://dx. doi.org/10.1016/S0167-2681(96)00857-8

Dong, S., L. Wen, S. Liu, X. Zhang, J. P. Lassoie, S. Yi, X. Li, J. Li, and Y. Li. 2011. Vulnerability of worldwide pastoralism to global changes and interdisciplinary strategies for sustainable pastoralism. Ecology and Society 16(2): 10. [online] URL: http: //www.ecologyandsociety.org/vol16/iss2/art10/

Dougill, A. J., E. D. G. Fraser, and M. S. Reed. 2010. Anticipating vulnerability to climate change in dryland pastoral systems: using dynamic systems models for the Kalahari. Ecology and Society 15(2): 17. [online] URL: http://www.ecologyandsociety.org/ vol15/iss2/art17/

Dufwenberg, M., U. Gneezy, W. Güth, and E. van Damme. 2001. Direct vs indirect reciprocity: an experiment. Homo Oeconomicus 18(1):19-30.

Fehr, E., and U. Fischbacher. 2002. Why social preferences matter - the impact of non-selfish motives on competition, cooperation and incentives. Economic Journal 112:C1-C33. http://d x.doi.org/10.1111/1468-0297.00027

Gintis, H. 2000. Beyond homo economicus: evidence from experimental economics. Ecological Economics 35(3):311-322. http://dx.doi.org/10.1016/ $\underline{\mathrm{S} 0921-8009(00) 00216-0}$

Gowdy, J. M. 2008. Behavioral economics and climate change policy. Journal of Economic Behavior \& Organization 68(3-4):632-644. http://d x.doi.org/10.1016/j.jebo.2008.06.011

Hastie, R., and R. M. Dawes. 2001. Rational choice in an uncertain world: the psychology of judgment and decision making. Sage, Thousand Oaks, California, USA.

Henrich, J., R. McElreath, A. Barr, J. Ensminger, C. Barrett, A. Bolyanatz, J. C. Cardenas, M. Gurven,
E. Gwako, N. Henrich, C. Lesorogol, F. W. Marlowe, D. Tracer, and J. Ziker. 2006. Costly punishment across human societies. Science 312 (5781):1767-1770. http://dx.doi.org/10.1126/scienc e. 1127333

Huntsinger, L., L. C. Forero, and A. Sulak. 2010. Transhumance and pastoralist resilience in the western United States. Pastoralism 1(1):1-36.

Janssen, M. A. 2010. Introducing ecological dynamics into common-pool resource experiments. Ecology and Society 15(2): 7. [online] URL: http:// www.ecologyandsociety.org/vol15/iss2/art7/

Janssen, M. A., R. Holahan, A. Lee, and E. Ostrom. 2010. Lab experiments for the study of socialecological systems. Science 328(5978):613-617. http://dx.doi.org/10.1126/science.1183532

Kanagaretnam, K., S. Stuart Mestelman, S. M. Khalid Nainar, and M. Shehata. 2010. Trust and reciprocity with transparency and repeated interactions. Journal of Business Research 63:241-247. http://dx.doi.org/10.1016/j.jbusres.200 $\underline{9.03 .007}$

Lefebvre, M., F. M. Vieider, and M. C. Villeval. 2010. Incentive effects on risk attitude in small probability prospects. Economics Letters 109 (2):115-120. http://dx.doi.org/10.1016/j.econlet.20 $\underline{10.09 .002}$

Manzano, P., and R. Casas. 2010. Past, present and future of trashumancia in Spain: nomadism in a developed country. Pastoralism 1(1):72-90.

McAllister, R. R. J., B. Cheers, T. Darbas, J. Davies, C. Richards, C. J. Robinson, M. Ashley, D. Fernando, and Y. T. Maru. 2008. Social networks in arid Australia: a review of concepts and evidence. Rangeland Journal 30(1):167-176. http://dx.doi.org /10.1071/RJ07040

McAllister, R. R. J., I. J. Gordon, M. A. Janssen, and N. Abel. 2006. Pastoralists' responses to variation of rangeland resources in time and space. Ecological Applications 16(2):572-583. http://dx.d oi.org/10.1890/1051-0761(2006)016[0572:PRTVOR] 2.0.CO;2

McAllister, R. R. J., and A. F. Reeson. 2007. An experimental approach to comparing trust in pastoral and non-pastoral Australia. Socio- 
Economics and the Environment in Discussion (SEED) Working Paper Series, CSIRO Sustainable Ecosystems, Canberra, Australia. [online] URL: http://www.csiro.au/resources/SEEDPaper9.html

Morton, S. R., D. M. Stafford Smith, C. R. Dickman, D. L. Dunkerley, M. H. Friedel, R. R. J. McAllister, J. R. W. Reid, D. A. Roshier, M. A. Smith, F. J. Walsh, G. R. Wardle, I. W. Watson, and M. Westoby. 2011. A fresh framework for the ecology of arid Australia. Journal of Arid Environments 75:313-329. http://dx.doi.org/10.1016/j.jaridenv.20 $\underline{10.11 .001}$

Müller, B., K. Frank, and C. Wissel. 2007. Relevance of rest periods in non-equilibrium rangeland systems - a modelling analysis. Agricultural Systems 92(1-3):295-317. http://dx.doi. org/10.1016/j.agsy.2006.03.010

Niamir-Fuller, M. 1998. The resilience of pastoral herding in Sahelian Africa. Pages 250-284 in F. Berkes and $\mathrm{C}$. Folke, editors. The resilience of pastoral herding in Sahelian Africa. Cambridge University Press, Cambridge, UK.

Ostrom, E., J. Walker, and R. Gardner. 1992. Covenants with and without a sword: selfgovernance is possible. American Political Science Review 86(2):404-417. http://dx.doi.org/10.2307/19 $\underline{64229}$

Perevolotsky, A. 1987. Territoriality and resource sharing among the Bedouin of southern Sinai: a socio-ecological interpretation. Journal of Arid Environments 13:153-161.

Prediger, S., B. Vollan, and M. Frölich. 2011. The impact of culture and ecology on cooperation in a common-pool resource experiment. Ecological Economics 70(9):1599-1608. http://dx.doi.org/10.1 $\underline{\text { 016/j.ecolecon.2010.08.017 }}$

Rapoport, A., J. A. Sundali, and D. A. Seale. 1996. Ultimatums in two-person bargaining with onesided uncertainty: demand games. Journal of Economic Behavior \& Organization 30(2):173-196. http://dx.doi.org/10.1016/S0167-2681(96)00856-6

Reeson, A. F., R. R. J. McAllister, S. M. Whitten, I. J. Gordon, M. Nicholas, and S. S. McDouall. 2008. The agistment market in the northern Australian rangelands: failings and opportunities. Rangeland
Journal 30(3):283-289. http://dx.doi.org/10.1071/R $\mathrm{J} 06042$

Reeson, A. F., J. G. Tisdell, and R. R. J. McAllister. 2011. Trust, reputation and relationships in grazing rights markets: an economic experimental study. Ecological Economics 70(4):651-658. http://dx.doi. org/10.1016/j.ecolecon.2010.10.013

Reynolds, J. F., D. M. Stafford Smith, E. F. Lambin, B. L. Turner, M. Mortimore, S. P. J. Batterbury, T. E. Downing, H. Dowlatabadi, R. J. Fernandez, J. E. Herrick, E. Huber-Sannwald, H. Jiang, R. Leemans, T. Lynam, F. T. Maestre, M. Ayarza, and B. Walker. 2007. Global desertification: building a science for dryland development. Science 316(5826):847-851. http://dx.doi.org/10.1126/science.1131634

Schmitt, P., K. Swope, and J. Walker. 2000. Collective action with incomplete commitment: experimental evidence. Southern Economic Journal 66(4):829-854. http://dx.doi.org/10.2307/1061532

Stafford Smith, D. M. 2008. The 'dryland syndrome' - causally-linked factors that characterise outback Australia. Rangeland Journal 30(1):3-14. http://dx. doi.org/10.1071/RJ07063

Tisdell, J. G., J. W. Ward, and T. Capon. 2004. Impact of communication and information on a complex heterogeneous closed water catchment environment. Water Resource Research 40. http://d x.doi.org/10.1029/2003WR002868 


\section{Appendix Instructions provided to experiment participants}

Supplementary material to the paper: McAllister, Tisdell, Reeson, Gordon, Economic Behaviour in the face of resource variability and uncertainty, Ecology and Society.

Before each experiment, participants were instructed on how the experimental protocol worked, and what the rules of the game were (see main paper). Participants were also given a test to ensure they understood the instructions. In this appendix we show the presentation given for the treatment which contained both the variability and rating elements. The control, ratings only and variability only presentations were modified versions of these presentations.

A1: Instructions for First Mover (rating \& variability)

A2: Instructions for Second Mover (rating \& variability) 


\section{A1: Instructions for First Mover (rating \& variability)}

\section{Introduction}

- In this experiment you will have the opportunity to form partnerships with other people

- Both players can earn extra money through a successful partnership

- However there is a risk that a partnership may be unprofitable

\section{Partnerships}

- A partnership consists of two players, a first mover (A) and a second mover (B)

- Each player begins each period with 100 cents

- Player A has the opportunity to transfer some money to player $B$

- Player B then has the opportunity to transfer money to player $A$

- The amount player B transfers to player A is multiplied

- Finally there will be an opportunity to rate your partner

\section{Partnerships}

- The multiplier means that overall income will be maximised if player $B$ makes a large transfer to player $\mathrm{A}$

- However, player B's income will be maximised by transferring little or nothing to player $\mathrm{A}$

\section{Partnerships}

- You have the opportunity to select a partner at the beginning of each round

- The experiment is anonymous, so you will never know who your partner was

- Your income for each round will be totalled and paid to you at the end of the experiment

\section{Procedure}

- Logging in

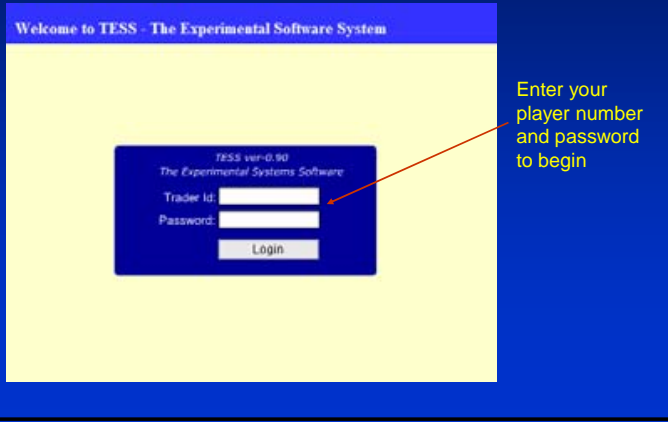

\section{How it works}

There are four stages in each round:

1) finding a partner

2) player $A$ transfers money to player $B$

3) player B transfers money to player $A$ (which is increased by a multiplier)

4) Provide a rating for your partner 


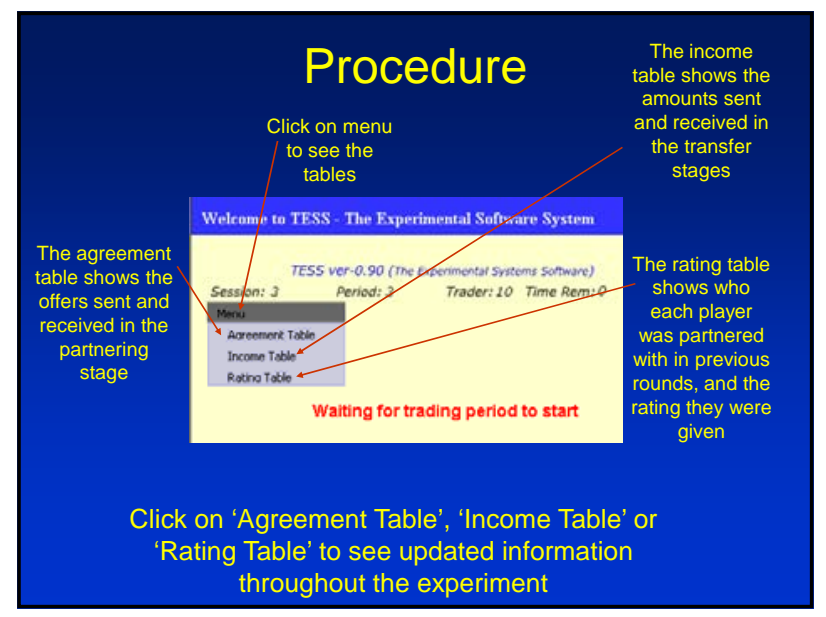

\section{Finding a Partner}

- You are in the role of Player A

- This means you can form a partnership with any player B, ie players 6-10

- Your agreement table will look like this:

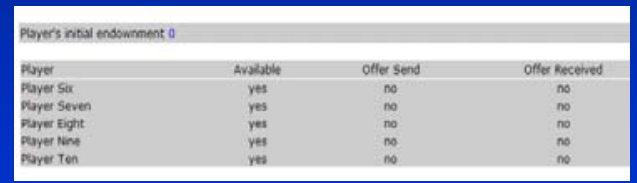

\section{Making and Receiving Offers}

$$
\begin{aligned}
& \text { If a player already } \\
& \text { has a partner, the } \\
& \text { table will show 'no' } \\
& \text { under available. } \\
& \text { You cannot make } \\
& \text { an offer to } \\
& \text { someone who is } \\
& \text { not available }
\end{aligned}
$$
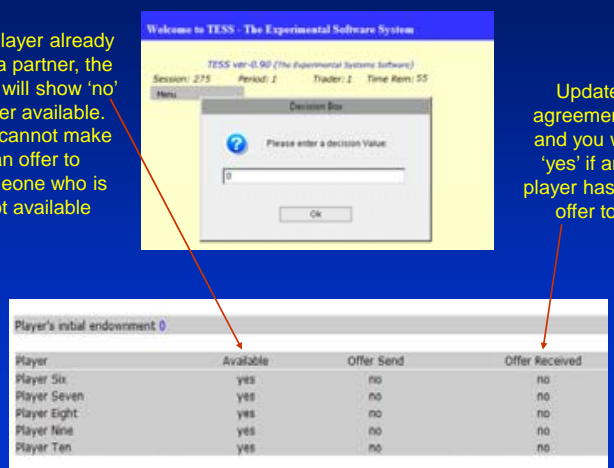

\section{Finding a Partner}

- Players 1-5 take the role of player A

- Players $6-10$ take the role of player B

- In the partner matching screen, As can offer to partner with Bs, and vice versa

- You can use the rating table to see how players were rated by previous partners

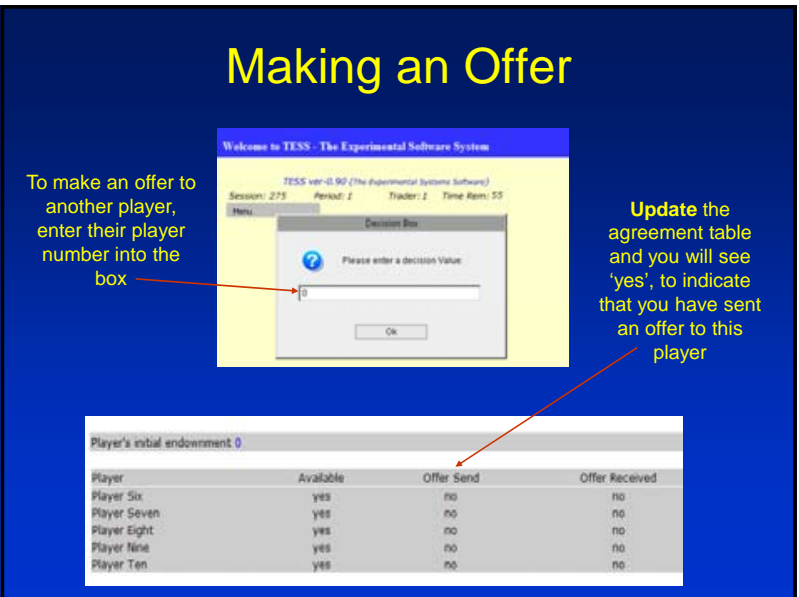

\section{Making and Receiving Offers}
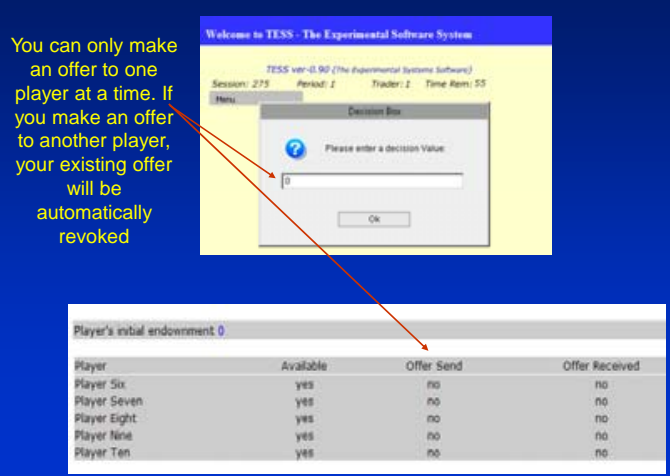


\section{A1: Instructions for First Mover (rating $\&$ variability)}

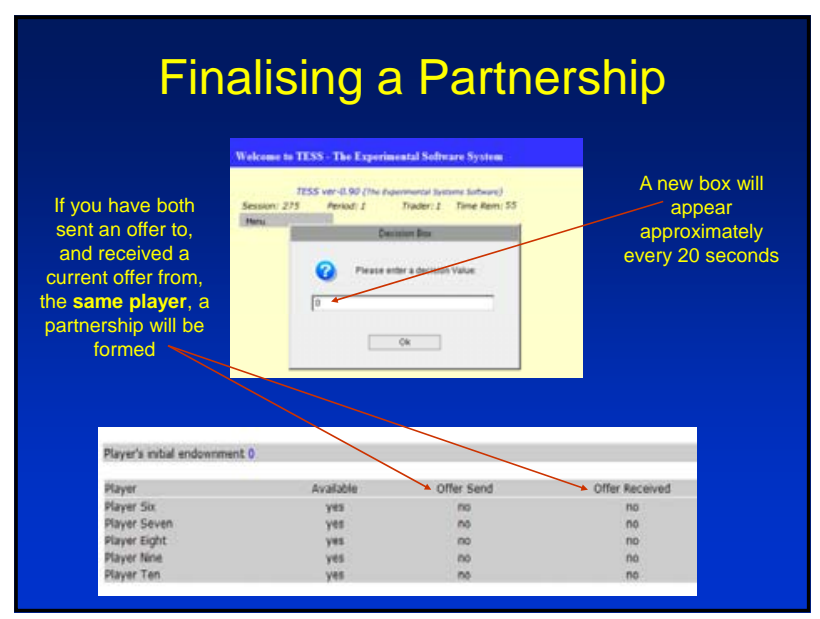

\section{Agreement Stage}

- Once you are in a partnership, you cannot make any further offers; wait for the transfer stage to begin

- If you send an offer to a player who is

unavailable, you will receive an error message

- You have a limited number of opportunities to make offers

- If you do not partner with anyone, you will make and receive no transfers, and your income for that round will be the 100c you were initially allocated

\section{Important Note}

- If you choose NOT to enter into a partnership, please enter a zero into the decision box

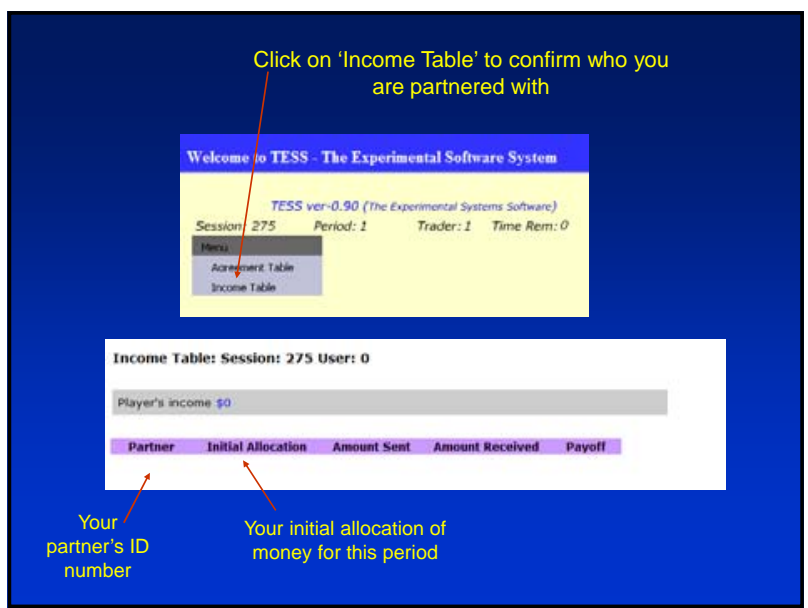

\section{First Transfer}

\section{First Transfer}

- Once the partnering stage is complete, the first transfer stage begins

- As player A, you must decide how much money to transfer to your partner

Enter the amount you wish to transfer into the decision box
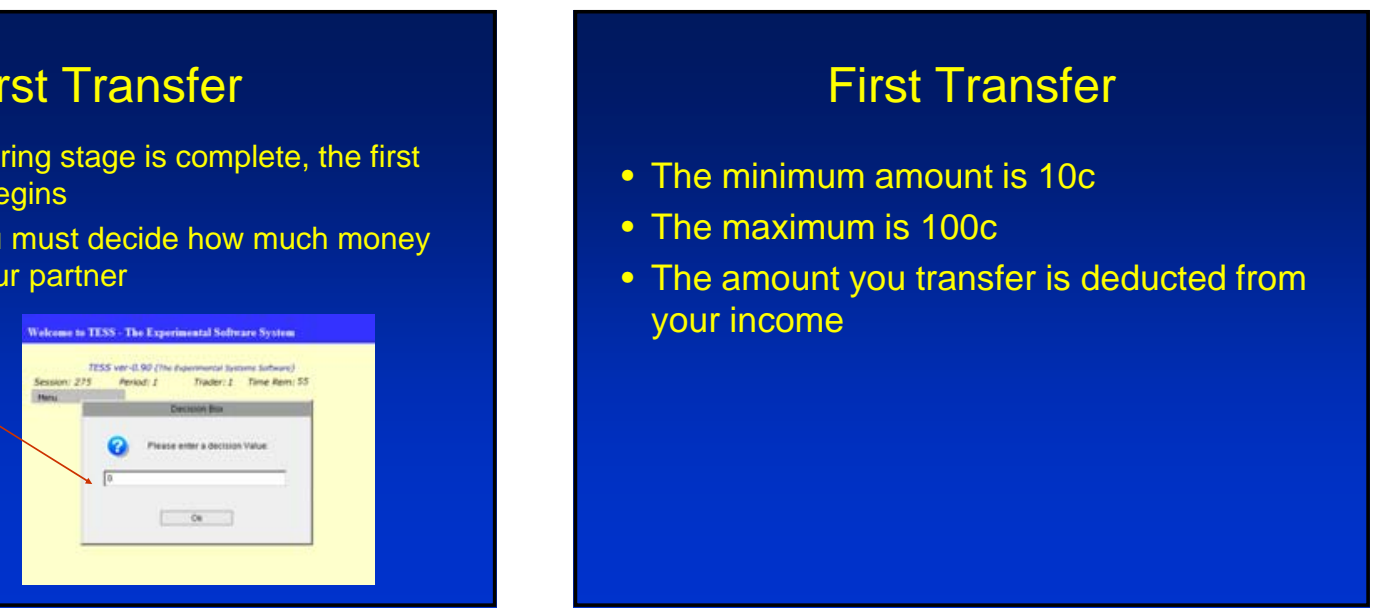


\section{A1: Instructions for First Mover (rating \& variability)}

\section{Second Transfer}

- Your partner now holds their initial 100c plus the amount transferred by you

- They must now decide how much to transfer back to you

- The minimum amount is $1 \mathrm{c}$, the maximum is $100 \mathrm{c}+$ amount received from you

- You will receive the amount transferred by your partner, increased by a multiplier

\section{The Multiplier}

- The amount transferred to you by your partner is increased by a multiplier

- The multiplier is a random number between two and six

- For example, if the multiplier is three, you will receive three times the amount transferred to you by your partner

- Only player B knows the multiplier

\section{Done Deal!}

The income table will show how much you sent to, and how much you received from, your partner, along with your total income for that round

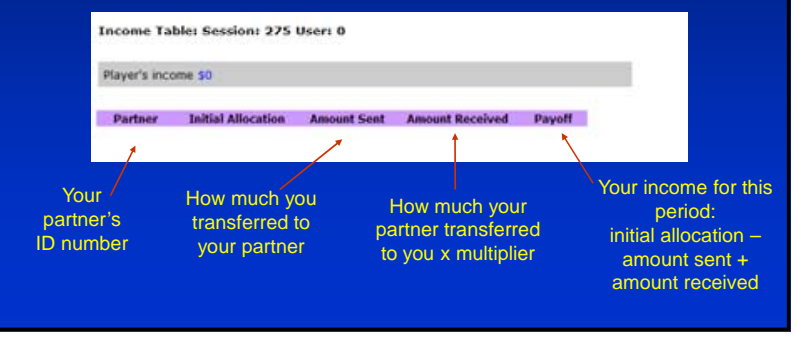

\section{Ratings}

- At the same time your partner will provide you with a rating

- Once everyone has made their decisions, the rating table will be updated to reveal everyone's scores

- Ratings do not directly affect your income, they simply provide information to other players

\section{Ratings}

- You then have the opportunity to provide a rating for your partner

- You can rate them 1, 2 or 3

- A rating of one indicates you are unhappy with your partner

- A rating of two is neutral

- A rating of three indicates you are happy with your partner

- Enter 1, 2 or 3 into the decision box

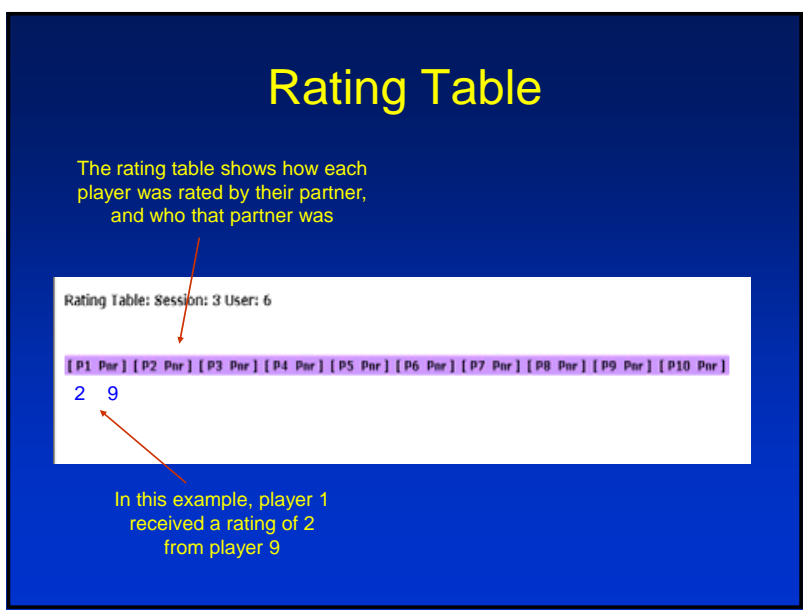




\section{A1: Instructions for First Mover (rating}

$\&$ variability)
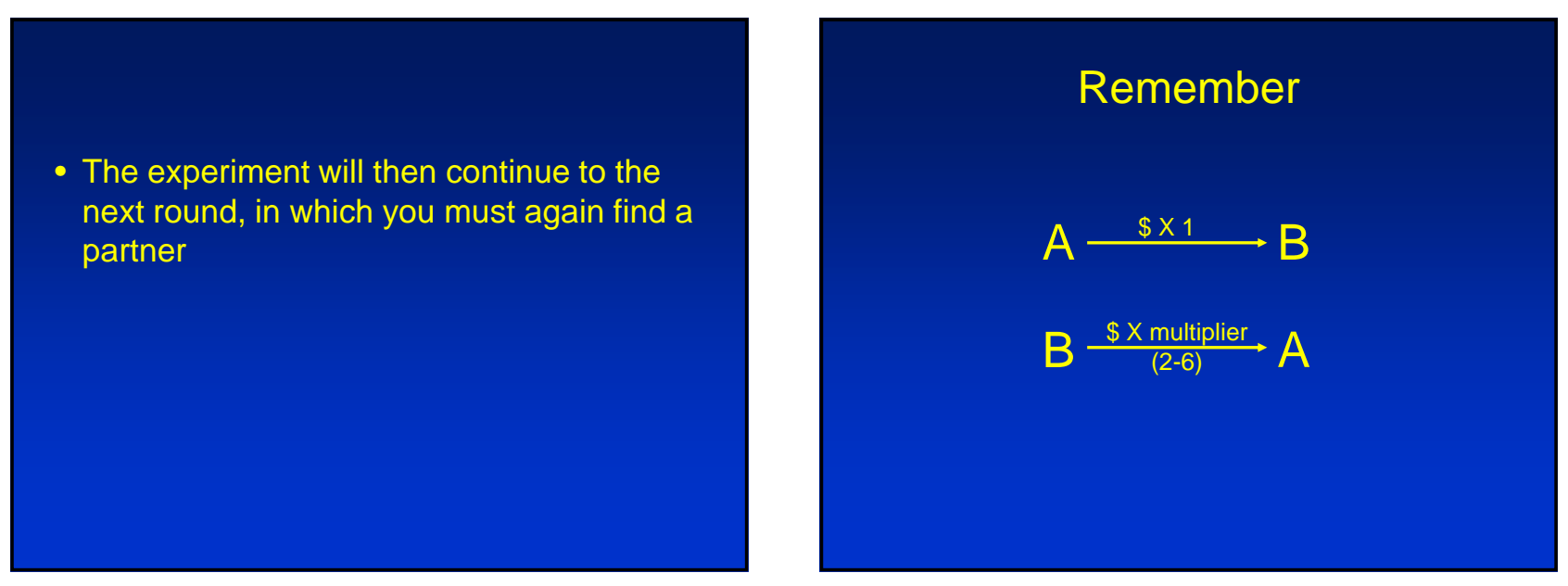

- These procedures may change over the course of the experiment, in which case you will be given a new set of instructions

- The decisions you make, and the amount of money you earn, are confidential

- Please do not talk or look at other screens during the experiment

- Please complete a short quiz to check your understanding of the instructions

- Please ask if you have any questions

Please go to the following URL:

http://www.ens.gu.edu.au/johnt/instructions/gbay4.xls 


\section{A2: Instructions for Second Mover (rating \& variability)}

\section{Introduction}

- In this experiment you will have the opportunity to form partnerships with other people

- Both players can earn extra money through a successful partnership

- However there is a risk that a partnership may be unprofitable

\section{Partnerships}

- A partnership consists of two players, a first mover (A) and a second mover (B)

- Each player begins each period with 100 cents

- Player A has the opportunity to transfer some money to player $\mathrm{B}$

- Player B then has the opportunity to transfer money to player $A$

- The amount player B transfers to player A is multiplied

- Finally there will be an opportunity to rate your partner

\section{Partnerships}

- The multiplier means that overall income will be maximised if player $B$ makes a large transfer to player $\mathrm{A}$

- However, player B's income will be maximised by transferring little or nothing to player A

\section{Partnerships}

- You have the opportunity to select a partner at the beginning of each round

- The experiment is anonymous, so you will never know who your partner was

- Your income for each round will be totalled and paid to you at the end of the experiment

\section{Procedure}

- Logging in

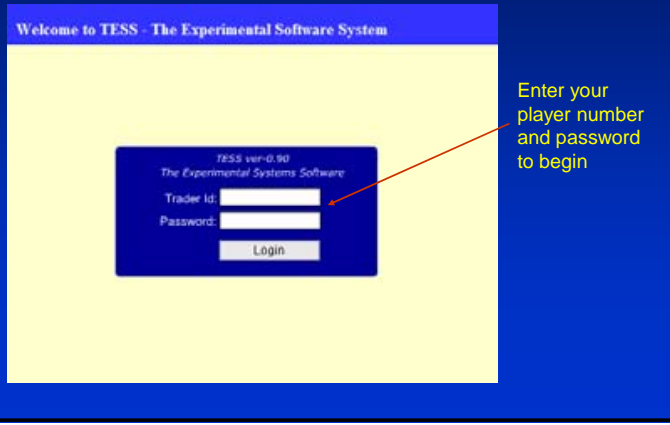

\section{How it works}

There are four stages in each round:

1) finding a partner

2) player A transfers money to player $B$

3) player $B$ transfers money to player $A$ (which is increased by a multiplier)

4) Provide a rating for your partner 


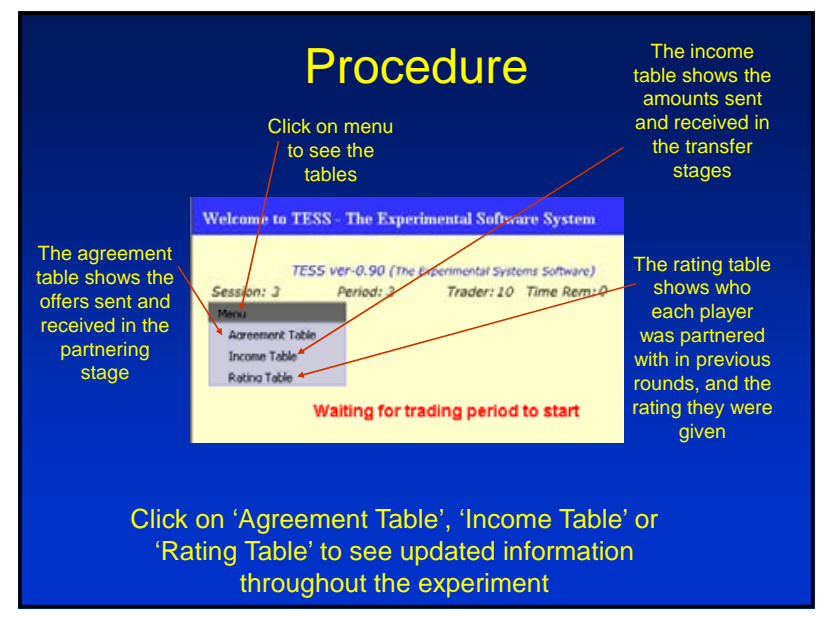

\section{Finding a Partner}

- You are in the role of Player B

- This means you can form a partnership with any player $A$, ie players 1-5

- Your agreement table will look like this:

\begin{tabular}{|c|c|c|c|}
\hline Your ritial entownment 0 & & inglee for this & \\
\hline Player & Aratita & OHere send & OHere Recetwes \\
\hline Player One & yes & no & $\infty$ \\
\hline Phyer Toto & yes & no & $\infty$ \\
\hline Pleyer Three & yes & no & $\infty$ \\
\hline Player Four & yes & no & \\
\hline Plove Five & & no & \\
\hline
\end{tabular}

\section{Finding a Partner}

- Players 1-5 take the role of player A

- Players $6-10$ take the role of player B

- In the partner matching screen, As can offer to partner with Bs, and vice versa

- You can use the rating table to see how players were rated by previous partners

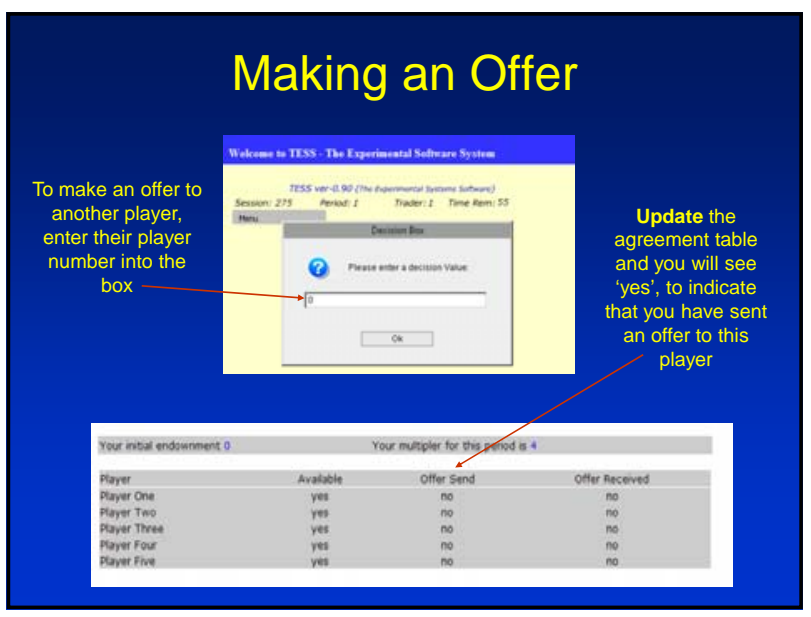

\section{Making and Receiving Offers}
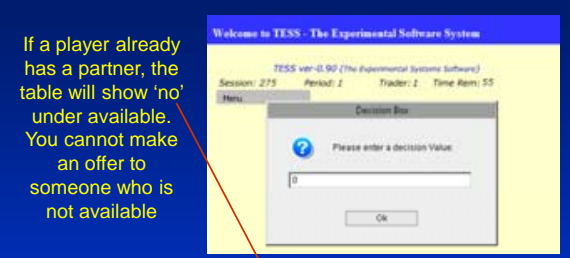

Update the

agreement table

and you will see

'yes' if another

player has sent an

not available

offer to you
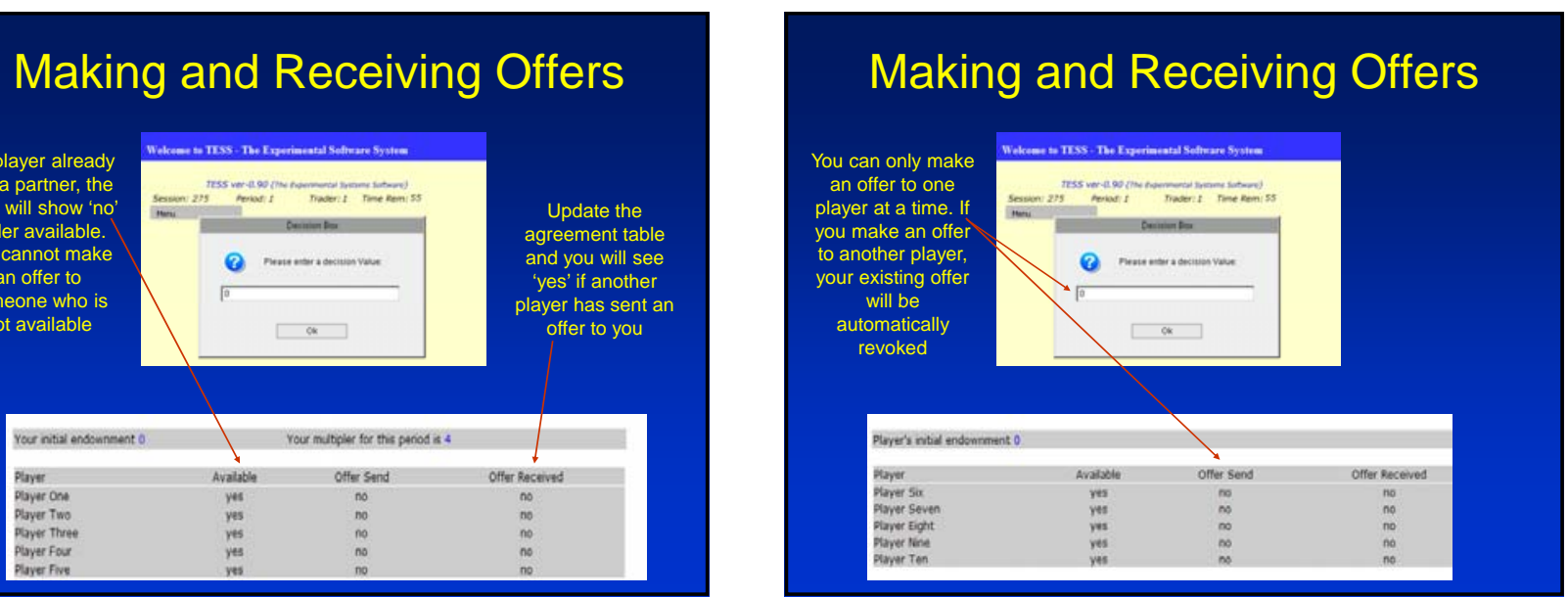


\section{A2: Instructions for Second Mover (rating \& variability)}

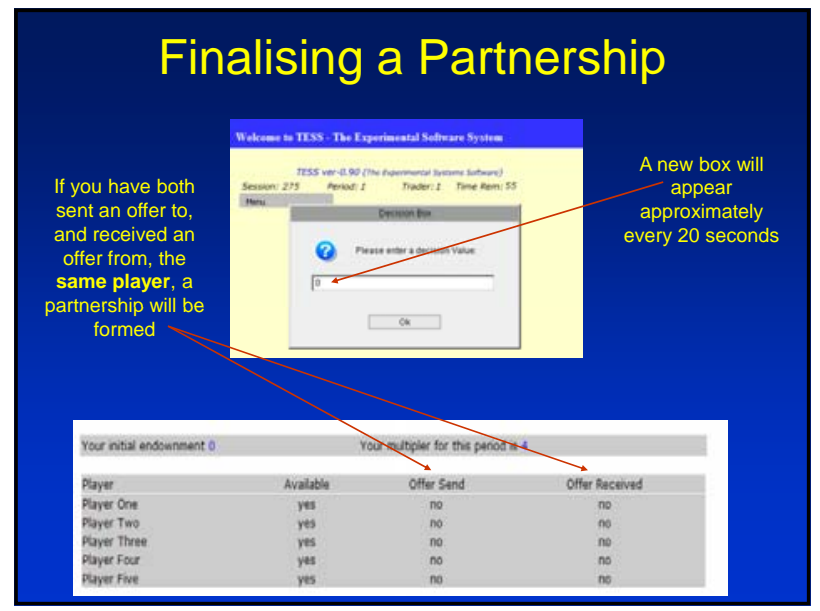

\section{Agreement Stage}

- Once you are in a partnership, you cannot make any further offers; wait for the transfer stage to begin

- If you send an offer to a player who is

unavailable, you will receive an error message

- You have a limited number of opportunities to make offers

- If you do not partner with anyone, you will make and receive no transfers, and your income for that round will be the 100c you were initially allocated

\section{Important Note}

- If you choose NOT to enter into a partnership, please enter a zero into the decision box

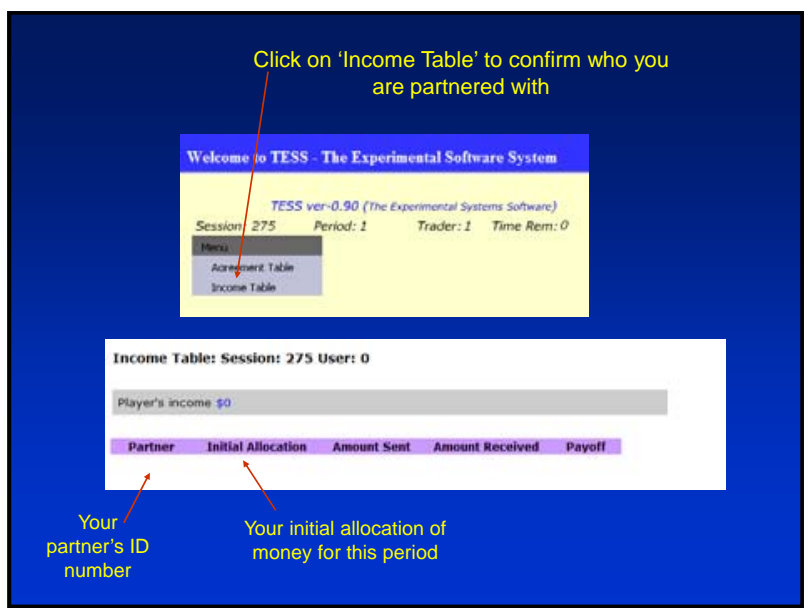

\section{First Transfer}

- Once the partnering stage is complete, the first transfer stage begins

- As player B, you must wait until your partner makes the first transfer

- Click on 'Income Table' to check whether an offer has been received yet

- The minimum transfer allowed for player $A$ is $10 \mathrm{c}$; the maximum is $100 \mathrm{c}$

\section{Second Transfer}

- Once you have received a transfer, you can make your transfer

- As player B, you must decide how much money to transfer to your partner

Enter the amount you wish to transfer into the decision box

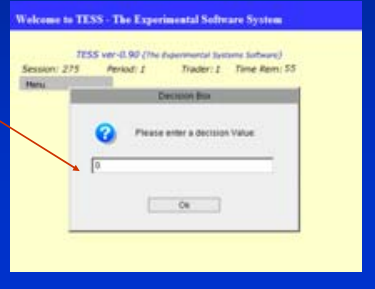




\section{A2: Instructions for Second Mover (rating \& variability)}

\section{Second Transfer}

- The minimum amount is $1 \mathrm{c}$

- The maximum is $100 \mathrm{c}+$ amount received from player A (ie everything you have)

- The amount you transfer is deducted from your income

- Your partner receives a multiple of the amount you transfer to them

\section{Done Deal!}

The income table will show how much you sent to, and how much you received from, your partner, along with your total income for that round

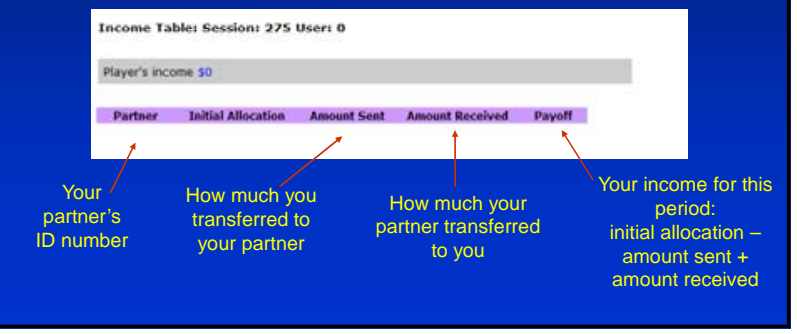

\section{Ratings}

- At the same time your partner will provide you with a rating

- Once everyone has made their decisions, the rating table will be updated to reveal everyone's scores

- Ratings do not directly affect your income, they simply provide information to other players

\section{The Multiplier}

- The amount transferred by you to your partner is increased by a multiplier

- The multiplier is a random number between two and six

- For example, if the multiplier is three, your partner will receive three times the amount transferred by you

- Only you (player B) knows the multiplier

\section{Ratings}

- You then have the opportunity to provide a rating for your partner

- You can rate them 1, 2 or 3

- A rating of one indicates you are unhappy with your partner

- A rating of two is neutral

- A rating of three indicates you are happy with your partner

- Enter 1, 2 or 3 into the decision box

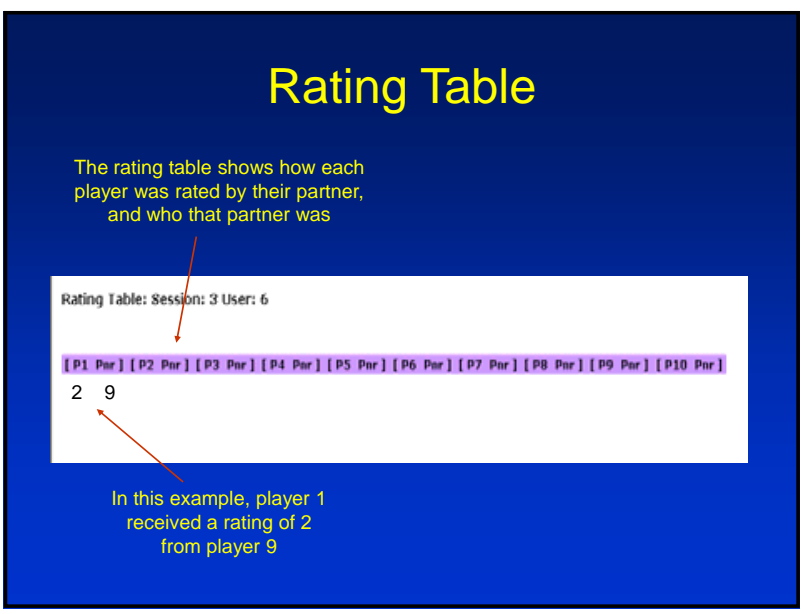



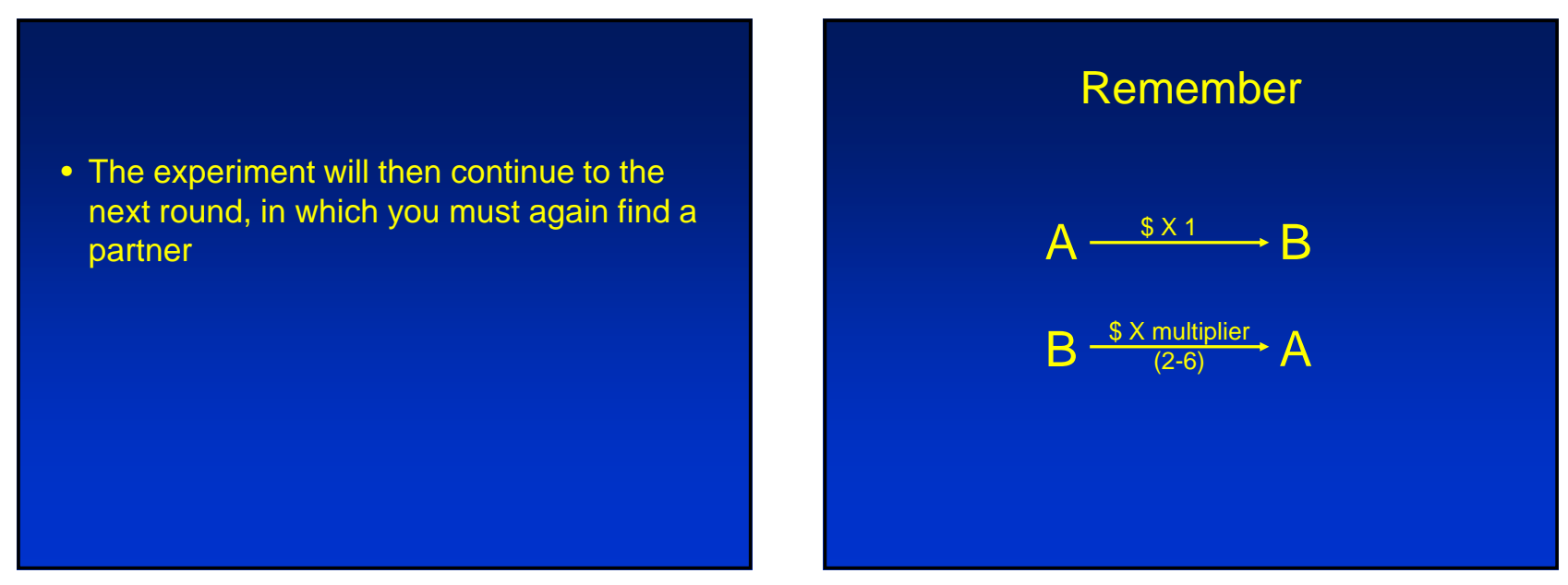

- These procedures may change over the course of the experiment, in which case you will be given a new set of instructions

- The decisions you make, and the amount of money you earn, are confidential

- Please do not talk or look at other screens during the experiment

- Please complete a short quiz to check your understanding of the instructions

- Please ask if you have any questions

Please open a new browser window and go to the following URL: 